\title{
Multiplication of Lymphocytic Choriomeningitis Virus in Cultivated Foetal Inbred Mouse Cells and in Neonatally Infected Inbred Carrier Mice
}

\author{
By H. VON BOEHMER, F. LEHMANN-GRUBE, \\ RENATE FLEMER AND R. HEUWINKEL \\ Heinrich-Pette-Institut für experimentelle Virologie und \\ Immunologie an der Universität Hamburg, 2 Hamburg 20, Martinistrasse 52, \\ Federal Republic of Germany \\ (Accepted 4 July 1974) \\ SUMMARY
}

The replication of infectious LCM virus and its complement-fixing antigen was followed in cultivated foetal cells from colony-bred albino mice, foetal cells from $\mathrm{CBA} / \mathrm{Ca}, \mathrm{C}_{3} \mathrm{H} / \mathrm{HeJ}, \mathrm{C}_{57} \mathrm{BL} / 6$, and $\mathrm{DBA} / 2$ inbred mice, and $\mathrm{L}$ cells. Typical $\mathrm{S}$-shaped growth curves were obtained in all instances and yields approached $\mathrm{IO}^{4}$ intracerebral mouse $\mathrm{ID}_{50} /$ cell. After the infection of newborn mice the multiplying virus rapidly reached a plateau of infectivity in tissues which remained thereafter. Ten weeks after neonatal infection the virus concentrations in blood and organs of ordinary albino mice and of $\mathrm{CBA}, \mathrm{C}_{3} \mathrm{H}, \mathrm{C}_{57} \mathrm{BL} / 6$, and $\mathrm{DBA} / 2$ inbred mice showed a wide range with highest levels in the kidneys and lowest in the blood.

The multiplication patterns and maximum yields of infectious virus and complement-fixing antigen were essentially identical in $\mathrm{L}$ cells and in foetal cells derived from five mouse strains; mutatis mutandis the same was true for persisting virus in the blood and organs of neonatal carrier mice.

\section{INTRODUCTION}

The interaction of lymphocytic choriomeningitis (LCM) virus with Mus musculus is regarded as an excellent model for the study of a variety of biological phenomena such as persistent virus infections, immunological tolerance, and pathological immune phenomena in virus diseases. Yet basic knowledge of the biological and physico-chemical properties of LCM virus is still limited. In this report, we describe the multiplication of the LCM virus in mice of inbred strains and in cell cultures derived from them. Differences between mouse strains were not observed.

\section{METHODS}

Mice. Inbred mice of the following strains were employed: $\mathrm{C}_{57}\left(\mathrm{C}_{57} \mathrm{BL} / 6 \mathrm{~J} \mathrm{BOM}\right)$ and DBA (DBA/2J/BOM) from Bomholtgård, Ry, Denmark; AKR and $\mathrm{C}_{3} \mathrm{H}\left(\mathrm{C}_{3} \mathrm{H} / \mathrm{HeJ}\right)$ from Jackson Laboratory, Bar Harbor, Maine; and CBA (CBA/Ca) from Animal Suppliers, London, U.K. Skin grafts between individuals of each strain were accepted permanently. The colony-bred albino mice (SCH) were from a local dealer.

Cell cultures. Growth medium for $\mathrm{L}$ cells consisted of minimum essential medium (MEM) (Eagle, 1959) supplemented with non-essential amino acids (Lockart \& Eagle, 1959) and $5 \%$ heat-inactivated ordinary calf serum (CaS). Foetal mouse cells were grown with MEM 
supplemented with $0.5 \%$ lactalbumin hydrolysate $(\mathrm{LaH})$ and $\mathrm{I0} \% \mathrm{CaS}$. The $\mathrm{pH}$ was maintained at $7 \cdot 2$ by means of $\mathrm{NaHCO}_{3}$, the concentration of which depended on the experimental conditions; at $37{ }^{\circ} \mathrm{C}$ and under $5 \% \mathrm{CO}_{2}$ this was $0.14 \%$. All media contained Ioo units of penicillin and $100 \mu \mathrm{g}$ of streptomycin per $\mathrm{ml}$.

Mouse L cells (NCTC clone 929), a permanent cell line of $\mathrm{C}_{3} \mathrm{H}$ mouse origin (Sanford, Earle \& Likely, 1948-49), were routinely propagated in Roux bottles. Attempts to clear these cells of an infection by Mycoplasma orale were unsuccessful. However, this contaminant seemed not to harm the cells which showed a log-phase generation time of $13.5 \mathrm{~h}$ and a consistent cloning efficiency close to $100 \%$.

For the cultivation of foetal mouse cells, near-term foetuses were minced with scissors and cells were released by the action of $0.25 \%$ trypsin. These were centrifuged and resuspended in growth medium, and $100 \mathrm{ml}$ containing $100 \times 10^{6}$ single cells and small clumps were seeded into Roux bottles to be used for preparing cultures in Petri dishes after incubation at $37^{\circ} \mathrm{C}$ for 2 days.

For cultural procedures, cells were counted after dispersal with trypsin. In conjunction with virus multiplication experiments, cells were counted as nuclei (Sanford et al. 1950-5I). The number thus determined was approximately twice the number of intact cells actually present (F. Lehmann-Grube, unpublished results).

Virus. Most experiments were done with LCM virus, strain WE (Rivers \& Scott, 1936) which had been provided by Professor W. Scheid, Cologne. It was propagated in L cells after two passages in L cells in this laboratory. Only in the experiment ' Replication of LCM virus in newborn mice' (see below) was a mouse-brain stock of virus used. Strain E-350 ('Armstrong') was obtained from the American Type Culture Collection. It was used after propagation in the mouse brain following intracerebral infection.

Strain CA I37 I was supplied by Dr W. P. Rowe, Bethesda, Md., as infected mouse brain. Its origin is obscure except that it came from the late Dr C. Armstrong and may be identical to strain E-350. Upon receipt, it was inoculated intracerebrally into $\mathrm{SCH}$ mice without passage in this laboratory, and a brain homogenate was used in these experiments. Appropriate tests showed that all three virus strains were free of the lactate dehydrogenaseelevating agent. Because of the great thermal lability of the LCM virus (Lehmann-Grube, I968), care was exercised to prevent loss of infectivity due to thermal inactivation. Thus, if virus had to be stored it was snap-frozen in small samples in ampoules and kept at $-70{ }^{\circ} \mathrm{C}$, and virus diluents always contained $\mathbf{r} \%$ heat-inactivated calf serum. Also, all manipulations involving virus were performed at $0{ }^{\circ} \mathrm{C}$.

Virus assay. Quantal titrations were made with 5 assay units per $0.5 \log _{10}$ dilution step. Usually, L cell tube cultures were used (Lehmann-Grube \& Hesse, 1967). In addition, numerous titrations were performed in mice (Lehmann-Grube, 1964), and these parallel assays confirmed the previously established relationships between $\mathrm{ID}_{50}$ ( $\mathrm{L}$ cell) and $\mathrm{ID}_{50}$ (mouse); the mouse was nine times more sensitive than the $\mathrm{L}$ cell tube culture for the WE strain of virus (Lehmann-Grube \& Hesse, 1967), 27 times more sensitive for the E-350 strain of virus, and 16 times more sensitive for the CA I37 I strain of virus (F. LehmannGrube, unpublished observations). In order to permit comparison of the present results with those of other laboratories, the results from experiments performed in vivo are always given as $\mathrm{ID}_{50}$ (mouse), whereas results from cell culture experiments are expressed as $\mathrm{ID}_{50}(\mathrm{~L}$ cell). It should be emphasized that our assays in mice are based on infection and give higher values than assays based on death $\left(\mathrm{LD}_{50}\right)$; the difference is $0.44 \log _{10}$ units for strain WE, $0.35 \log _{10}$ units for strain E-350 (Lehmann-Grube, 1971), and $0.47 \log _{10}$ units for strain CA I37I (F. Lehmann-Grube, unpublished observations). 
Complement fixation (CF) test. CF antigen (Ag) was measured by means of a microtechnique (Sever, 1962). Antiserum was prepared in rabbits which were immunized with WE strain virus propagated in primary rabbit kidney cells employing rabbit serum in growth and maintenance medium. The complement unit has been taken as the vol. of guinea pig serum required for lysis of $50 \%$ of $3 \times 10^{6}$ sensitized sheep red cells after $60 \mathrm{~min}$ at $37^{\circ} \mathrm{C}$ in a vol. of $0.125 \mathrm{ml}$. In the main test two complement units and antiserum in excess were employed. The Ag titre is defined as the reciprocal of that $\mathrm{Ag}$ sample dilution at which $50 \%$ haemolysis occurs; this gives the Ag concentration in units per $0.025 \mathrm{ml}$.

Multiplication of LCM virus, strain WE, in mouse cells in vitro. L cell monolayers in Roux bottles were dispersed by means of trypsin, and $10^{6}$ cells in $5 \mathrm{ml}$ of growth medium consisting of MEM plus $0.5 \% \mathrm{LaH}$ and $10 \% \mathrm{CaS}$ were seeded into $5 \mathrm{~cm}$ plastic Petri dishes (C. A. Greiner u. Söhne, Nürtingen). After incubation for $48 \mathrm{~h}$ at $37{ }^{\circ} \mathrm{C}$ under $5 \% \mathrm{CO}_{2}$ the media were exchanged against $0.5 \mathrm{ml}$ of MEM without serum containing $10^{3} \mathrm{ID}_{50}$ (L cell) of LCM virus. Adsorption at room temperature was terminated after $60 \mathrm{~min}$ by removing the inoculum and washing the cells once with balanced salt solution (BSS) (Hanks \& Wallace, 1949). Five $\mathrm{ml}$ of pre-warmed $\left(37^{\circ} \mathrm{C}\right)$ virus multiplication medium consisting of MEM, non-essential amino acids (Lockart \& Eagle, I 959), and 10\% CaS were then added (time 0 ), and incubation was at $37^{\circ} \mathrm{C}$ in a humidified and gassed incubator. At intervals, three cultures were taken and immediately cooled to $0^{\circ} \mathrm{C}$. The cells from two cultures were scraped separately into the media, and cells plus media were treated with an ultrasonic drill (Mullard, U.K.) under conditions known to disrupt the cells but not to affect virus infectivity (Lehmann-Grube, 1968). The resulting homogenates containing virus were dispersed into ampoules and stored at $-70^{\circ} \mathrm{C}$ until titrated. The third culture was used for counting cells as nuclei at the time of harvest.

Secondary cultures of foetal mouse cells were prepared, infected, and harvested in the same manner.

Multiplication of LCM virus in newborn mice. SCH mice, less than $24 \mathrm{~h}$ old, were infected intraperitoneally with $\mathrm{IO}^{3} \mathrm{ID}_{50}$ (mouse) $\mathrm{LCM}$ virus. Immediately after infection and then at $24 \mathrm{~h}$ intervals, three mice from at least two litters were killed. Snout, skin, and guts were removed, and from the combined carcasses a $10 \%$ homogenate $(\mathrm{w} / \mathrm{v})$ was prepared with a mortar using as diluent BSS plus $\mathrm{I} \%$ inactivated CaS. Samples were kept at $-70{ }^{\circ} \mathrm{C}$ until titration.

Determination of virus concentration in blood and organs of carrier mice. Mice were infected intraperitoneally with $10^{3} \mathrm{ID}_{50}$ (mouse) when less than $24 \mathrm{~h}$ old. At the age of 8 to 12 weeks they were killed. Blood was immediately diluted Io-fold with BSS, containing Io units/ml of heparin. Kidneys, brain, and liver were ground individually in mortars with a little sand, and a $10 \%(\mathrm{w} / \mathrm{v})$ homogenate was made with BSS. Diluted blood and organ homogenates were dispersed by sonic treatment and centrifuged for $10 \mathrm{~min}$ at $4000 \mathrm{~g}$. Supernatant fluids were titrated as soon as possible.

\section{RESULTS}

Experiments in vitro

\section{Multiplication of LCM virus-infected mouse cells}

During the log-phase of growth our uninfected L cells multiplied with doubling times of I 3 to $14 \mathrm{~h}$. After infection with virus of WE strain, multiplication was reduced though not abolished. The multiplication rates of normal foetal mouse cells have not been determined. However, these cells too did not stop increasing in number after infection. 

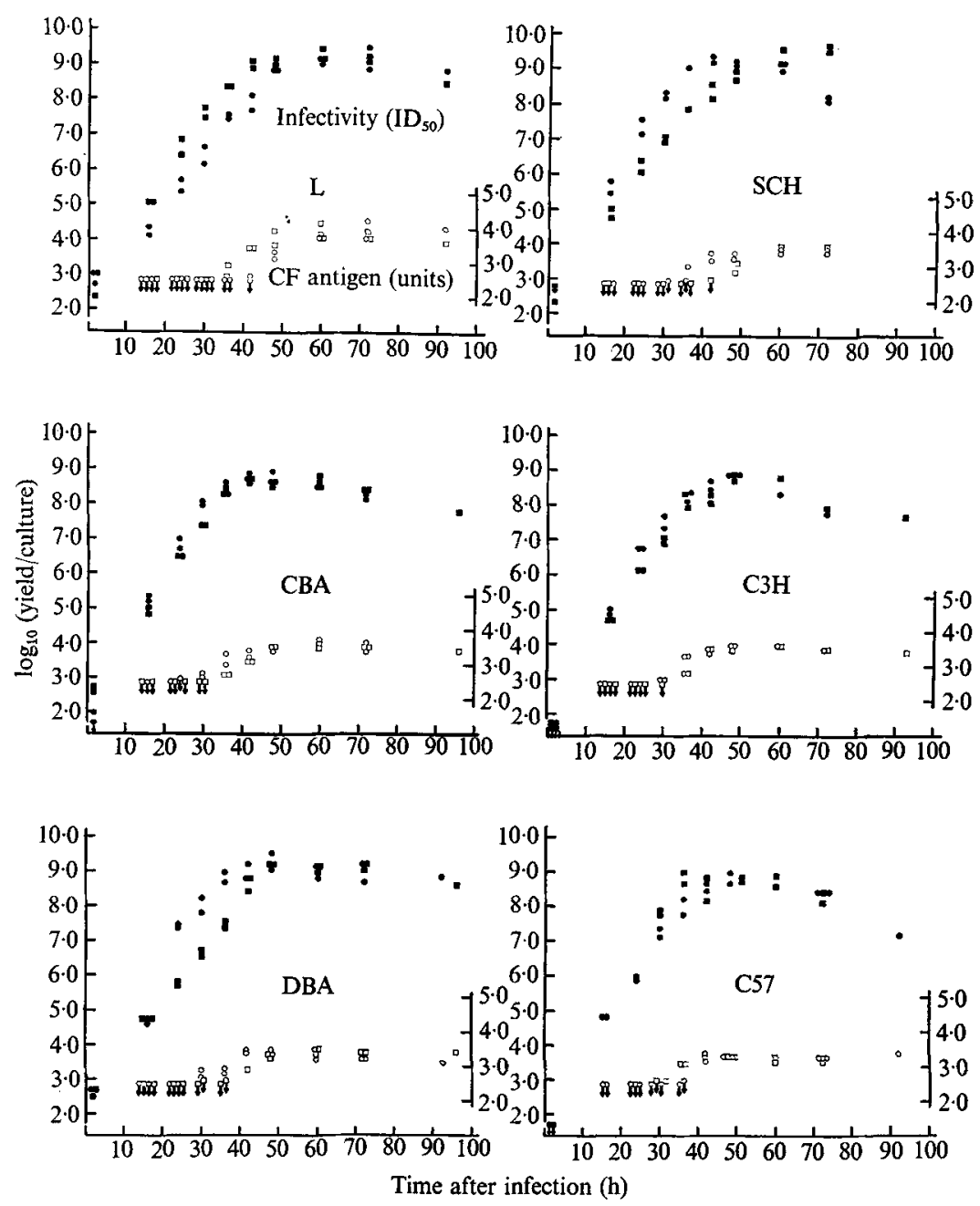

Fig. I. Multiplication of LCM virus, strain WE, in cultivated $L$ cells and foetal cells from outbred SCH and inbred CBA, $\mathrm{C}_{3} \mathrm{H}, \mathrm{DBA}$, and $\mathrm{C}_{57}$ mice. Cultures were infected with $10^{3} \mathrm{ID}_{50}(\mathrm{~L}$ cell), and after periods of incubation at $37^{\circ} \mathrm{C}$ total yields of infectious virus and of complement-fixing antigen were determined in $\mathrm{L}$ cell tube cultures and on micro-assay plates, respectively. Titres are expressed as $\log _{10}\left(\mathrm{ID}_{50} \mathrm{~L}\right.$ cell) and $\log _{10}$ antigen units per culture. Squares and circles denote results from separate experiments.

Morphological alterations of virus-infected cells were not apparent during the greater part of the observation period. Beyond the 6oth $\mathrm{h}$ degenerative changes became visible which were seen but less pronounced in control cultures.

\section{Production of infectious virus}

Multiplication of infectious virus in mouse cells in vitro is depicted in Fig. I. Little or no virus was demonstrable $2 \mathrm{~h}$ after infection. By $\mathrm{I} 6 \mathrm{~h}$ progeny virus had appeared in considerable quantities, and for the next $20 \mathrm{~h}$ virus production was logarithmic. There was a plateau between the $42 \mathrm{nd}$ and 6oth $\mathrm{h}$ and, towards the end of the observation period, the infectivities dropped again, presumably because of diminished replication combined with 


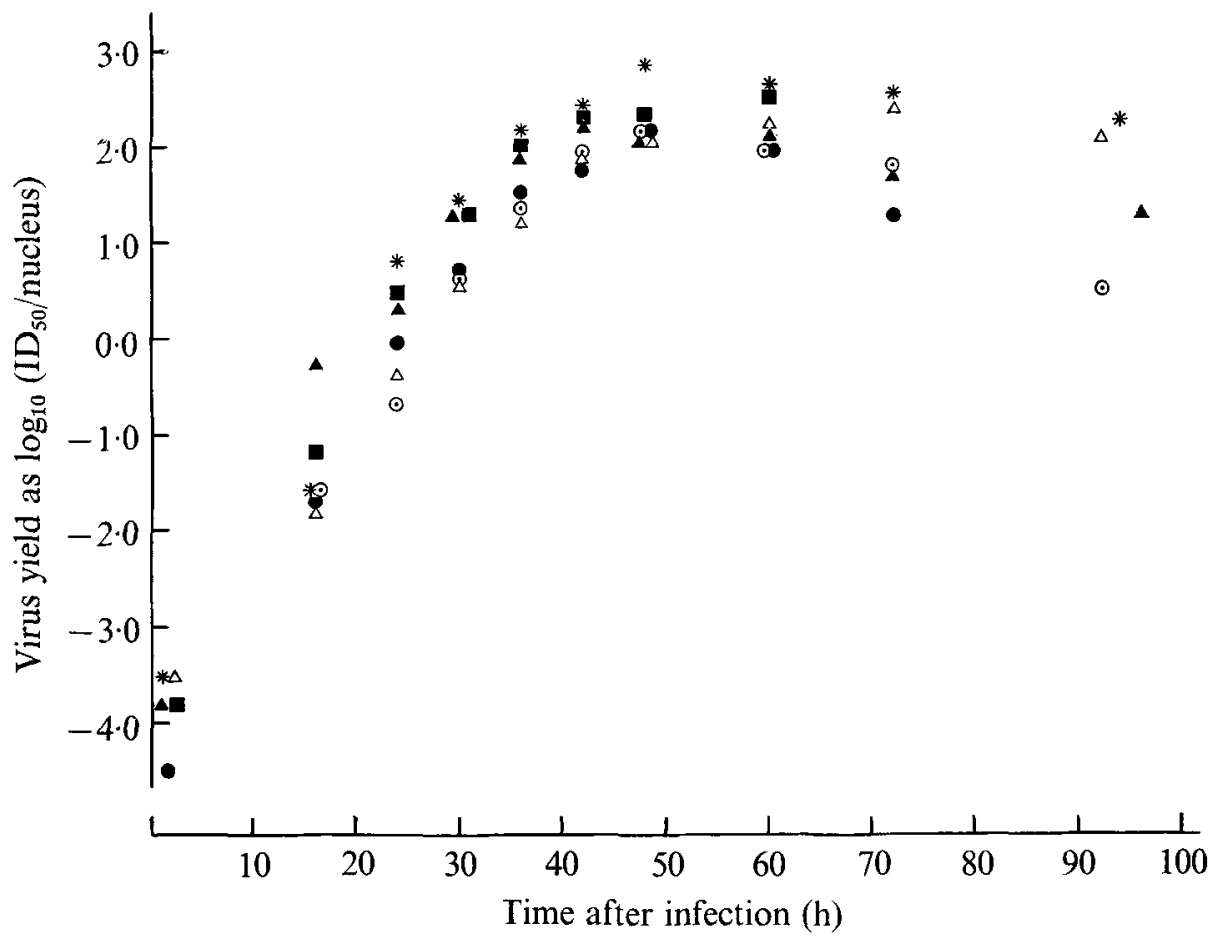

Fig. 2. Yield of infectious LCM virus of strain WE from cultivated mouse cells. Cultures were infected with $10^{3} \mathrm{ID}_{50}$ ( $\mathrm{L}$ cell). After incubation at $37^{\circ} \mathrm{C}$ cells and media were harvested for the determination of infectious virus in $\mathrm{L}$ tube cultures (see Fig. I). At the same time the nuclei of parallel cultures were counted. Yields are expressed as $\mathrm{ID}_{50}(\mathrm{~L}$ cell)/cell nucleus. $\triangle, \mathrm{L}$ cells; $\mathrm{SCH} ; A, \mathrm{CBA} ; \odot, \mathrm{C}_{3} \mathrm{H} ;{ }^{*}, \mathrm{DBA} ; \odot, \mathrm{C} 57$.

Table I. Yield/cell nucleus of infectious LCM virus of strain WE in mouse cell cultures during the plateau phase of virus growth

\begin{tabular}{|c|c|c|c|c|}
\hline \multirow{2}{*}{$\begin{array}{l}\text { Source of } \\
\text { foetal mouse } \\
\text { cells }\end{array}$} & \multicolumn{4}{|c|}{ Time after infection (h) } \\
\hline & 42 & 48 & 60 & Mean \\
\hline & \multicolumn{4}{|c|}{$\mathrm{ID}_{50}(\mathrm{~L}$ cell)/cell nucleus* } \\
\hline $\mathrm{SCH}$ & 229 & 200 & 347 & 259 \\
\hline $\mathrm{C}_{57}$ & 87 & I 55 & n.c. $\dagger$ & I $2 \mathrm{I}$ \\
\hline CBA & I 66 & I 29 & I I 7 & I 37 \\
\hline $\mathrm{C}_{3} \mathrm{H}$ & 62 & I 55 & 96 & 104 \\
\hline DBA & 275 & 692 & 417 & $46 \mathrm{I}$ \\
\hline $\mathrm{L}$ & 69 & 115 & 191 & 125 \\
\hline
\end{tabular}

thermal inactivation. A feature of the growth curves was their close similarity. This is also apparent in the comparison of virus yields per cell nucleus (Fig. 2). In order to define these similarities more quantitatively, the virus yields during the plateau phases were averaged for each cell type. Analysis of variance of these data (Table $\mathrm{r}$ ) revealed that the mean square within classes (mouse strains) exceeded that between means of classes, though not to a significant degree, and hence the maximal yields did not differ between $\mathrm{L}$ cells and $\mathrm{SCH}$, $\mathrm{C}_{3} \mathrm{H}, \mathrm{CBA}, \mathrm{DBA}$, or $\mathrm{C}_{57}$ foetal mouse cells. 
Table 2. Lethality among mice of different strains neonatally infected with $L C M$ virus of strain $W E$

$\begin{array}{lc}\text { Strain } & \text { Lethality* } \\ \text { SCH } & 0 / 56, \quad 0 \% \\ \text { C57 } & 18 / 45, \quad 40 \% \\ \text { CBA } & 80 / 105,76 \% \\ \text { DBA } & 28 / 32,88 \% \\ \text { C3H } & 58 / 65, \quad 89 \% \\ \text { AKR } & 80 / 80, \quad 100 \%\end{array}$

* Number of mice dead between 6 th and 25 th day after intraperitoneal inoculation of $10^{3} \mathrm{ID}_{50}$ (mouse) over number inoculated.

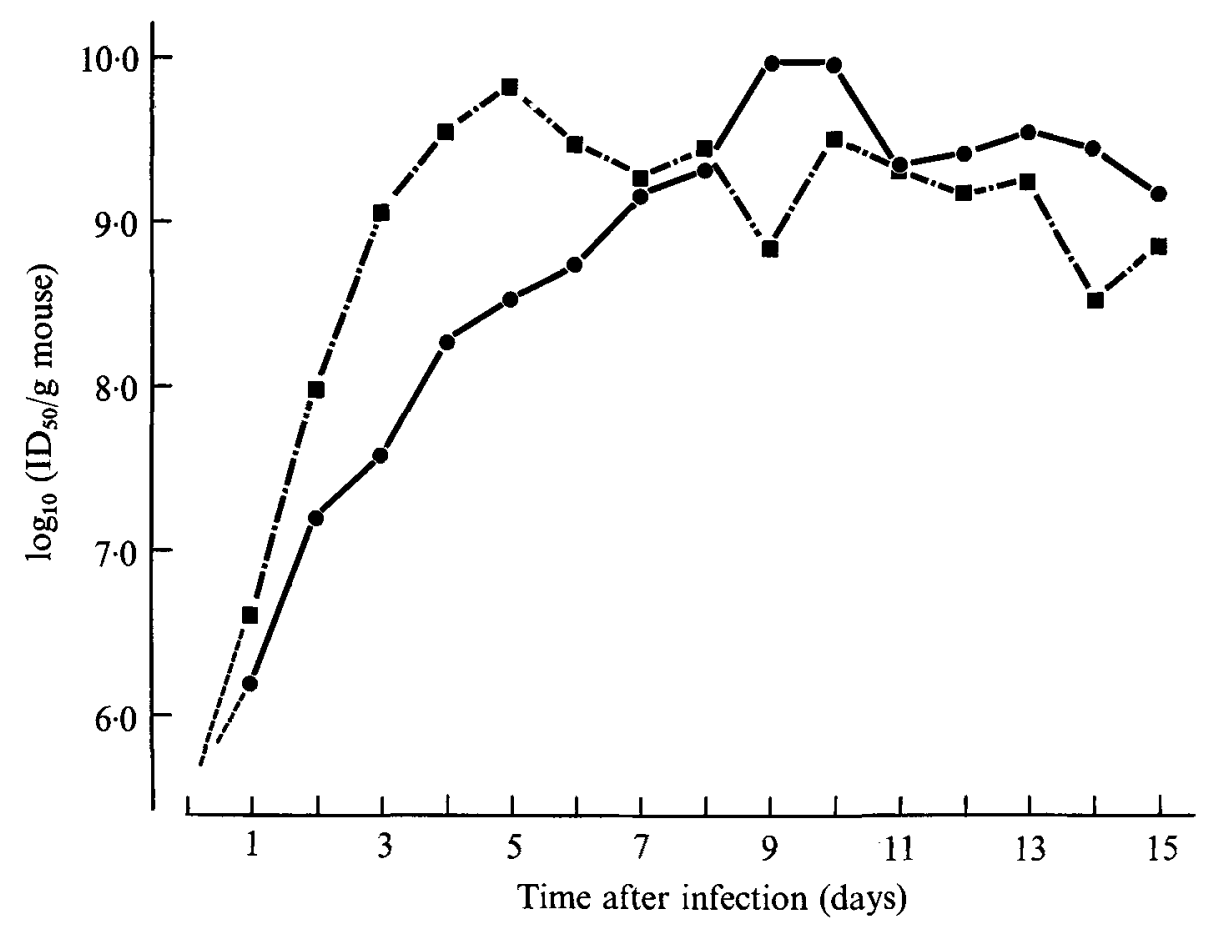

Fig. 3. Multiplication of LCM virus, strains E-350 ('Armstrong') and WE, in newborn SCH mice. Mice, less than $24 \mathrm{~h}$ old, were infected intraperitoneally with $\mathrm{IO}^{3} \mathrm{ID}_{50}$ (mouse), and at intervals the virus concentrations of whole carcasses were determined. Infectious virus was assayed in $L$ cell tube cultures and infectivities are expressed as $\mathrm{ID}_{50}$ (mouse)/g. - $-\mathrm{E}-350 ; \mathbf{\square -}-\mathbf{-}$, WE.

Strictly, a statistical treatment of the data in Table I is of little value because of uncertainty whether the experimental error is distributed linearly (as assumed to be the case) or logarithmically. Thus, if the data are converted to $\log$ values, analysis of variance leads to entirely different results; the mean square between classes then exceeds the mean square within classes by a factor of $F=6.79$, and this difference is highly significant. However, the differences between the heights of the plateau phases for the mouse strains seen in Fig. I, whether statistically significant or not, are not large enough to permit conclusions as to their biological or genetic relevance. 
Table 3. Concentration of infectious LCM virus of strain $W E$ in blood and organs of carrier mice $10 \pm 2$ weeks after neonatal infection

\begin{tabular}{|c|c|c|c|c|c|}
\hline \multirow[b]{2}{*}{ Organ } & \multicolumn{5}{|c|}{ Strain of mice } \\
\hline & $\mathrm{SCH}$ & $\mathrm{C}_{57}$ & CBA & $\mathrm{C}_{3} \mathrm{H}$ & DBA \\
\hline \multicolumn{6}{|c|}{ Mean $\log _{10} \mathrm{ID}_{50}$ (mouse) $/ \mathrm{I} \mathrm{ml}$ blood or $\mathrm{I} \mathrm{g}$ tissue \pm single standard error* } \\
\hline $\begin{array}{l}\text { Blood } \\
\text { Brain } \\
\text { Liver } \\
\text { Kidney }\end{array}$ & $\begin{array}{l}5 \cdot 76 \pm 0.11(5) \\
7 \cdot 29 \pm 0.13(5) \\
6.88 \pm 0.17(4) \\
8.50 \pm 0.19(5)\end{array}$ & $\begin{array}{l}5.86 \pm 0.09(3) \\
7.05 \pm 0.18(6) \\
7.52 \pm 0.22(7) \\
8.38 \pm 0.11(7)\end{array}$ & $\begin{array}{l}5.52 \pm 0.15(5) \\
7.33 \pm 0.08(6) \\
7.53 \pm 0.34(6) \\
8.38 \pm 0.08(6)\end{array}$ & $\begin{array}{l}5.87 \pm 0.22(5) \\
7.57 \pm 0.14(5) \\
7.17 \pm 0.19(5) \\
8.68 \pm 0.05(4)\end{array}$ & $\begin{array}{l}6.27 \pm 0.15(6) \\
7.66 \pm 0.16(4) \\
7.78 \pm 0.18(7) \\
8.47 \pm 0.10(7)\end{array}$ \\
\hline
\end{tabular}

Table 4. Concentration of infectious LCM virus of strain CA $137 \mathrm{x}$ in blood and organs of carrier $\mathrm{C}_{3} \mathrm{H}$ mice $\mathrm{IO} \pm 2$ weeks after neonatal infection Mouse Blood Brain Kidney $\mathrm{ID}_{50}$ (mouse) per $\mathrm{I} \cdot \mathrm{O} \mathrm{ml}$ blood or $\mathrm{I} \cdot 0 \mathrm{~g}$ tissue

I
2
3
4
5
6
Mean and single
standard error

\begin{tabular}{|c|c|c|c|}
\hline 5.90 & 6.88 & 6.64 & 7.92 \\
\hline $6 \cdot 3 \mathrm{I}$ & 7.21 & 7.04 & $7 \cdot 84$ \\
\hline $5 \cdot 46$ & $6 \cdot 9 I$ & $8 \cdot 27$ & $8 \cdot 14$ \\
\hline $5 \cdot 71$ & 6.65 & $7 \cdot 21$ & $8 \cdot 54$ \\
\hline n.d. & 6.96 & $7 \cdot 85$ & $8: 41$ \\
\hline 5.08 & n.d. & n.d.* & n,d. \\
\hline \pm 0.21 & $6.92 \pm 0.09$ & $7 \cdot 40 \pm 0.29$ & $8 . \mathrm{I} 7 \pm 0.14$ \\
\hline
\end{tabular}

* Not done.

\section{Production of complement-fixing antigen ( $C F A g$ )}

The yields of CF Ag and infective virus are represented together in Fig. I. As a rule, CF Ag passed the threshold of detection around the 30 th $\mathrm{h}$. It then increased and, again, there were no differences between the types of mouse cells investigated, either in rates of production or in maximum yields.

\section{Experiments in vivo}

\section{Lethality in newborn mice after LCM virus infection}

The general experience that newborn mice survive infection with the LCM virus irrespective of dose and route of inoculation was confirmed here with $\mathrm{SCH}$ mice; none died when 56 such animals were inoculated intraperitoneally with $\mathrm{IO}^{3} \mathrm{ID}_{50}$ (mouse) when less than one day old. Contrary to expectation, however, all inbred mice developed signs of severe disease after the 7 th day of infection and most died (Table 2). Lethality was not reduced by increasing the virus dose or by using inbred litters nursed by SCH foster mothers.

\section{Replication of LCM virus in newborn mice}

Following the infection of newborn SCH albino mice, both the WE and E-350 strains of LCM virus grew rapidly, although strain E-350 was somewhat slower. By day 7 both viruses had reached maximum concentrations and these did not change during the rest of the I5 days of observation (Fig. 3). 
Table 5. Concentration of complement-fixing antigen in organs of LCM virus strain WE carrier mice $10 \pm 2$ weeks after neonatal infection

\begin{tabular}{|c|c|c|c|c|c|}
\hline \multirow[b]{2}{*}{ Organ } & \multicolumn{5}{|c|}{ Strain of mice } \\
\hline & $\mathrm{SCH}$ & $\mathrm{C}_{57}$ & CBA & $\mathrm{C}_{3} \mathrm{H}$ & DBA \\
\hline \multicolumn{6}{|c|}{ Mean $\log _{10} \mathrm{CF}$ Ag units per $0.025 \mathrm{~g} \pm$ single standard error* } \\
\hline Brain & $\begin{aligned} & 3.08 \\
\pm & 0.09(5)\end{aligned}$ & $\begin{aligned} & 3 \cdot 18 \\
\pm & 0 \cdot 10(4)\end{aligned}$ & $\begin{aligned} & 3.24 \\
& \pm 0.06(4)\end{aligned}$ & $\begin{aligned} & 2.94 \\
\pm & 0.1 \text { I (4) }\end{aligned}$ & $\begin{array}{l}\geqslant 3.24 \\
( \pm 0.12)(4)\end{array}$ \\
\hline Liver & $\begin{aligned} & 2.55 \\
\pm & 0.24(4)\end{aligned}$ & $\begin{aligned} & 3 \cdot 11 \\
\pm & 0.15(6)\end{aligned}$ & $\begin{aligned} & 3.28 \\
\pm & 0.16(4)\end{aligned}$ & $-^{3 \cdot 25}(1)$ & $\begin{aligned} & 3 \cdot 19 \\
\pm & 0 \cdot 13(7)\end{aligned}$ \\
\hline Kidney & $\begin{array}{l}\geqslant 3.32 \\
( \pm 0.15)(5)\end{array}$ & $\begin{aligned} & 3.33 \\
\pm & 0.06(6)\end{aligned}$ & $\begin{aligned} & 3.36 \\
\pm & 0.05(6)\end{aligned}$ & $\begin{aligned} & 3.39 \\
\pm & 0.08(4)\end{aligned}$ & $\begin{array}{c}\geqslant 3.52 \\
( \pm 0.01)(7)\end{array}$ \\
\hline
\end{tabular}

Concentration of LCM virus in blood and organs of adult carrier mice

A synopsis of the results of virus titrations of blood and organ homogenates from adult mice infected neonatally is presented in Table 3. For a given organ the different mouse strains showed no significant differences in infectivity greater than that expected from sampling variation. In contrast, there were differences between organs, and the highest infectivities were observed for kidneys and the lowest for blood. We then investigated another virus strain and again the concentrations of infectious virus in blood and organs of $\mathrm{C}_{3} \mathrm{H}$ mice persistently infected with the CA I37 I strain of LCM virus were high and comparable to the concentrations of $\mathrm{WE}$ virus in $\mathrm{C}_{3} \mathrm{H}$ and other mouse strains (Table 4 ).

\section{Concentration of complement-fixing antigen in the organs of carrier mice}

Owing to high anticomplementary activities, the determination of CF Ag in the blood of carrier mice was not possible. The titres of the organ homogenates (Table 5) confirmed the findings with infectious virus and differences between mouse strains were not significant.

\section{DISCUSSION}

The laboratory model of LCM disease of the mouse is seen as an allergic phenomenon (Hotchin, 1962); direct effects of the infecting virus on the cell are assumed to be absent (Lehmann-Grube, 197I). However, when cells in vitro are infected, they are usually adversely affected to some extent, and under certain experimental conditions morphological alterations may be detected. In the present experiments frank cytolysis was not apparent, even at a time when virus infectivities were maximal and $90 \%$ or more of the cells were filled with immunofluorescing antigen, but cell multiplication was slower and degeneration faster than for non-infected control cells.

Multiplication of the Traub strain of LCM virus in L cell suspension cultures was followed by Pedersen \& Volkert (1966). Lehmann-Grube \& Slenczka (I967) and Lehmann-Grube (197r) determined the behaviour of the WE strain in L cell monolayer cultures. Under these conditions the latent period did not vary with the input multiplicity; progeny virus appeared after $8 \mathrm{~h}$ and was largely cell-associated. Knowledge of the production of CF Ag in mouse cells in vitro is also fragmentary.

The present study indicates that the amount of infectious virus produced must be regarded as very high. Taking into account that the assay in $\mathrm{L}$ cell tube cultures underestimates the number of infectious units by at least a factor of 9 , and that enumeration of cells on the basis of nuclei overestimates the actual cell number by a factor of about 2 , each figure of 
the last column in Table I must be increased 18 -fold and hence, for instance in the case of cells from DBA strain foetal mice, approx. $8000 \mathrm{ID}_{50}$ of LCM virus of strain WE were produced per cell. A feature of our results is the similarity of virus production between $L$ cells and foetal mouse cells originating from colony-bred albino mice or from inbred mice of strains CBA, $\mathrm{C}_{3} \mathrm{H}, \mathrm{DBA}$, and $\mathrm{C}_{57}$. Oldstone, Habel \& Dixon (1969) reported differences of virus yields between foetal mouse cells in vitro from different inbred mouse strains.

The determination of the virus concentrations in blood and organs from carrier mice was difficult because of the high mortality after neonatal infection of inbred mice. While no SCH mice died during the period of observation, most inbred mice died after infection under the same conditions, and all AKR mice died. It should be pointed out that a few years ago Lehmann-Grube, then working in Marburg/Lahn, experienced no difficulty in establishing carrier mice of the same inbred strains, although even then more inbred mice died than did colony-bred albino mice. We know of no cause which satisfactorily explains the differences between mouse strains or the fluctuation within strains.

In contrast to cell cultures, in which the observation period was curtailed because of virus-induced and/or spontaneous degeneration of the cells, no such experimental limitation applied to the mouse. Having confirmed observations by others (Volkert \& Hannover Larsen, 1965) that after neonatal infection a plateau of virus concentration is rapidly reached and maintained thereafter, the age of 8 to $I 2$ weeks was chosen to determine the virus contents of blood and organs of SCH albino and four inbred strain carrier mice. Again no differences between mouse strains in respect of either infectious virus or CF Ag were found. This uniformity is in marked contrast to the results reported by Oldstone \& Dixon (1968) who, employing the CA I37I strain of LCM virus, found a gradient from high virus concentrations in SWR mice to very low concentrations in $\mathrm{C}_{3} \mathrm{H} / \mathrm{HeJ}$ mice. However, even when we followed Oldstone \& Dixon's protocol as closely as possible, using the same strain of virus and the same strain of mice, the concentrations of CA I37I strain virus in the organs of neonatally infected $\mathrm{C}_{3} \mathrm{H} / \mathrm{HeJ}$ mice were about 200 -fold higher in blood and more than 10000-fold higher in kidneys than had been observed by them. Hoffsten \& Dixon (I973) produced neonatal $\mathrm{C}_{3} \mathrm{H}$ and SWR carrier mice with the CA I37I strain of LCM virus. At 2 to 10 months old the virus infectivities of sera ranged between $3 \cdot 4$ to $4 \cdot \mathrm{I} \log _{10}$ $\mathrm{LD}_{50}$ (mouse) per $0.03 \mathrm{ml}$, which corresponds closely to the values determined here. Also there were no significant differences between the two mouse strains. Volkert \& Hannover Larsen (1965) and Hannover Larsen (1973) worked with the Traub strain of LCM virus and found relatively high virus infectivities in $\mathrm{C}_{3} \mathrm{H}$ carrier mice.

The uniformity of inbred mouse strains in their ability to support LCM virus multiplication either in vitro or in vivo was also unexpected in view of the influence genetic factors are known to have on multiplication of other viruses (e.g. arboviruses, oncornaviruses) even in members of one species (Webster, \& Clow, 1936; Webster \& Johnson, 194I; Sabin, 1952; Vogt \& Ishizaki, 1965; Hartley, Rowe \& Huebner, 1970; Pincus, Hartley \& Rowe, 1971). Of course, only few mouse strains were used and an extension may reveal differences which would increase our experimental tools for studying the relationship between LCM virus and the mouse.

This work was supported by a research grant from the Deutsche Forschungsgemeinschaft. 


\section{REFERENCES}

EAGLE, H. (1959). Amino acid metabolism in mamalian cell cultures. Science, New York r30, $432-437$.

HANKS, J. H. \& WALLACE, R. E. (1949). Relation of oxygen and temperature in the preservation of tissues by refrigeration. Proceedings of the Society for Experimental Biology and Medicine 71, 196-200.

HANNOVER LARSEN, J. ( I 973). Murine LCM virus infection: tolerance and immunity. In Lymphocytic Choriomeningitis Virus and Other Arenaviruses, I39-1 50. Edited by F. Lehmann-Grube. Berlin, Heidelberg, New York: Springer-Verlag.

HARTLEY, J. W., ROWE, W. P. \& HUEBNER, R. J. (1970). Host-range restrictions of murine leukemia viruses in mouse embryo cell cultures. Journal of Virology 5, $22 \mathrm{I}-225$.

HOFFSTEN, P. E. \& DIXON, F. J. (I973). Effect of immunosuppression on chronic LCM virus infection of mice. Journal of Experimental Medicine 138, 887-899.

нотснIN, J. (I962). The biology of lymphccytic choriomeningitis infection: virus-induced immune disease. Cold Spring Harbor Symposia on Quantitative Biology 27, 479-499.

LEHMANN-GRUBE, F. (I964). Lymphocytic choriomeningitis in the mouse. I. Growth in the brain. Archiv für die gesamte Virusforschung 14, 344-350.

LEHMANN-GRUBE, F. (I968). Untersuchungen über das Virus der lymphozytären Choriomeningitis. I. Stabilisierung des Virus. Archiv für die gesamte Virusforschung 23, 202-217.

LEHMANN-GRUBE, F. (197I). In Lymphocytic Choriomeningitis Virus. Virology Monographs, vol. Io. Wien, New York: Springer-Verlag.

LEHMANN-GRUBE, F. \& HESSE, R. (1967). A new method for the titration of lymphocytic choriomeningitis viruses. Archiv für die gesamte Virusforschung 20, 256-259.

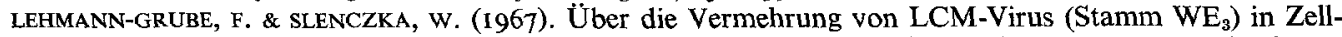
kulturen. Zentralblatt für Bakteriologie, Parasitenkunde und Infektionskrankheiten. I. AbteilungReferate 206, 525 .

LOCKART, R. Z. \& EAGLE, H. (1959). Requirements for growth of single human cells. Science, New York 129, $252-254$.

OLDSTONE, M. B. A. \& DIXON, F. J. (I968). Susceptibility of different mouse strains to lymphocytic choriomeningitis virus. Journal of Immunology I00, 355-357.

OLDSTONE, M. B. A., HABEL, K. \& DIXON, F. J. (I969). The pathogenesis of cellular injury associated with persistent LCM viral infection. Federation Proceedings 28, 429.

PEDERSEN, I. R. \& VOLKERT, M. (I966). Multiplication of lymphocytic choriomeningitis virus in suspension cultures of Earle's strain L cells. Acta pathologica et microbiologica Scandinavica 67, 523-536.

PINCUS, T., HARTLEY, J. W. \& ROWE, W. P. (I97I). A major genetic locus affecting resistance to infection with murine leukemia viruses. I. Tissue culture studies of naturally occurring viruses. Journal of Experimental Medicine I33, I219-1 233.

RIVERS, T. M. \& SCOTT, T. F. M. (I936). Meningitis in man caused by a filterable virus. II. Identification of the etiological agent. Journal of Experimental Medicine 63, 41 5-432.

SABIN, A. B. (I952). Genetic, hormonal and age factors in natural resistance to certain viruses. Annals of the New York Academy of Sciences 54, 936-944.

SANFORD, K. K., EARLE, W. R., EVANS, V. J., WALTZ, H. K. \& SHANNON, J. E. (I950-5I). The measurement of proliferation in tissue cultures by enumeration of cell nuclei. Journal of the National Cancer Institute II, $773-795$.

SANFORD, K. K., EARLE, W. R. \& LIKELY, G. D. (1948-49). The growth in vitro of single isolated tissue cells. Journal of the National Cancer Institute 9, 229-246.

SEVER, J. L. (1962). Application of a microtechnique to viral serological investigations. Journal of Immunology 88, 320-329.

VOGT, P. K. \& ISHIZAKI, R. (I965). Reciprocal patterns of genetic resistance to avian tumor viruses in two lines of chickens. Virology 26, 664-672.

VOLKERT, M. \& HANNOVER LARSEN, J. (1965). Studies on immunological tolerance to LCM virus. 5. The induction of tolerance to the virus. Acta pathologica et microbiologica Scandinavica 63, I6I-17I.

WÉBSTER, L. T. \& CLOW, A. D. (1936). Experimental encephalitis (St Louis type) in mice with high inborn resistance. Journal of Experimental Medicine 63, 827-845.

WEBSTER, L. T. \& JOHNSON, M. S. (I94I). Comparative virulence of St Louis encephalitis virus cultured with brain tissue from innately susceptible and innately resistant mice. Journal of Experimental Medicine $\mathbf{7 4}$, 489-494.

(Received 25 February 1974) 